\title{
PROCJENE USLUGA ŠUMSKIH EKOSUSTAVA I OPĆEKORISNIH FUNKCIJA ŠUMA PARK ŠUME MARJAN U SPLITU
}

\author{
ASSESSMENT OF FOREST ECOSYSTEM SERVICES \\ AND NON-MARKET FOREST FUNCTIONS IN PARK FOREST \\ MARJAN SPLIT
}

Ivica TIKVIĆ ${ }^{1}$, Damir UGARKOVIĆ ${ }^{1}$, Ivan PELES², Ivan KNEŽIĆ3 ${ }^{3}$, Gabrijela MEDUNIĆ-ORLIĆ ${ }^{4}$ Srđan MARINIĆ ${ }^{5}$, Lukrecija BUTORAC ${ }^{6}$, Antonela ČMRLEC ${ }^{7}$, Robert KOHAREVIĆ7, Marija NAZLIĆ4, Slađana PAVLINOVIĆ ${ }^{8}$, Matea ŠPIKA4 ${ }^{4}$ Robertina TOMIĆ

\begin{abstract}
Sažetak
Usluge šumskih ekosustava i funkcije šuma imaju slično značenje, iako se djelomično razlikuju. Funkcije šuma se odnose na namjenu i svrhu šuma od kojih ljudi imaju koristi, dok su usluge šumskih ekosustava posljedice i rezultati funkcija šuma, odnosno koristi od ekosustava za čovjeka i okoliš. Usluge šumskih ekosustava se odnose na sve funkcije šuma, dok se općekorisne funkcije šuma (OKFŠ) odnose samo na one funkcije šuma od kojih svi ljudi imaju koristi. Park šuma Marjan (PŠM) sa svojim različitim ekosustavima pruža brojne usluge i koristi stanovnicima Splita, posjetiteljima park šume i drugim organizmima.

U Park šumi Marjan koja je površine od oko 300 ha, najzastupljeniji su šumski ekosustavi koji zauzimaju 2/3 park šume. U radu je po prvi puta definirano 28 usluga šumskih ekosustava PŠM na temelju međunarodne podjele usluga ekosustava i drugih podjela OKFŠ. Pomoću anketnog upitnika napravljeno je rangiranje tih usluga. Pet najvažnijih usluga šumskih ekosustava bile su stvaranje čistog i svježeg zraka, pružanje prirodnog prostora za rekraciju, pružanje prirodnog prostora za odmor, stvaranje kisika i pružanje prirodnog prostora za edukativne aktivnosti. Procjena novčanih vrijednosti pet najvažnijih usluga šumskih ekosustava napravljena je na temelju određenih kriterija i indikatora. Procijenjene vrijednosti pojedinih najvažnijih usluga šumskih ekosustava iznosile su od 700 do 77.000 kn po hektaru godišnje. Procijenjena ukupna vrijednost pet najvažnijih usluga šumskih ekosustava iznosila je 122.000 kn po ha godišnje, odnosno oko 24,4 milijuna kn godišnje za 200 ha šuma PŠM. Napravljena je i aproksimativna procjena vrijednosti preostalih 23 usluge šumskih ekosustava PŠM. Ukupna procijenjena vrijednost svih 28 usluga šumskih ekosustava PŠM iznosila je oko 708.000 kn po ha godišnje, odnosno oko 141,6 milijuna kn godišnje za 200 ha šuma PŠM. Analizirane su i vrijednosti općekorisnih funkcija šuma do-
\end{abstract}

\footnotetext{
1 Prof. dr. sc. Ivica Tikvić, ivica.tikvic@zg.htnet.hr, ' ${ }^{1}$ doc. dr. sc. Damir Ugarković, damir.urgarkovic@gs.htnet.hr, Sveučilište u Zagrebu Šumarski fakultet, Zavod za ekologiju i uzgajanje šuma, Svetošimunska 25, 10002 Zagreb, Hrvatska

${ }_{2}^{2}$ Ivan Peles, univ. bacc. ing. silv., ipeles100@yahoo.com, Odvoja Vjekoslava Klaića 9, 10430 Samobor, Hrvatska

${ }^{3}$ Ivan Knežić, mag. ing. silv., trava1992@net.hr, Zvekovac 27, 10342 Dubrava, Hrvatska

${ }^{4}$ Gabrijela Meduni-Orlić dipl. ing. kemije, gabrijela@sunce-st.org, ${ }^{4}$ Marija Nazlić, mag. educ. biol. et. chem, marija.nazlic@sunce-st.org, ${ }^{4}$ Matea Špika, mag. sc. upravljanja zaštićenim područjem, matea.spika@sunce-st.org, Udruga za prirodu, okoliš i održivi razvoj Sunce, Obala hrvatskog narodnog preporoda 7/3, 21000 Split, Hrvatska

${ }^{5}$ Srđan Marinić, srdan.marinic@gmail.com, ${ }^{5}$ Robertina Tomić, robertinat@gmail.com, Društvo Marjan, Obala hrvatskog narodnog preporoda 25, 21000 Split, Hrvatska

${ }^{6}$ Dr. sc. Lukrecija Butorac, lukrecija.butorac@krs.hr, Institut za jadranske kulture i melioraciju krša, Put Duilova 11, 21000 Split, Hrvatska

${ }^{7}$ Antonela Čmrlec struč. spec. oecc., promocija@marjan-parksuma.hr, ${ }^{7}$ Robert Koharević dipl. ing. agr., ravnatelj@marjan-parksuma.hr, Javna ustanova za upravljanje Park šumom Marjan, Teslina 15, 21000 Split, Hrvatska

${ }^{8}$ doc. dr. sc. Slađana Pavlinovic, sladjana.pavlinovic@efst.hr, Sveučilište u Splitu Ekonomski fakultet, Cvite Fiskovića 5, 21000 Split, Hrvatska
} 
bivene na temelju procjene općekorisnih funkcija šuma prema programu gospodarenja za PŠM, zatim na temelju procjene općekorisnih funkcija mediteranskih šuma i na temelju godišnjeg iznosa naknade za općekorisne funkcije šuma. Procjene su iznosile od $200 \mathrm{kn}$ do $402.000 \mathrm{kn}$ po ha godišnje. Procjene novčanih vrijednosti usluga ekosustava, pa tako i šumskih ekosustava, imaju važnu ulogu u planovima zaštite, upravljanja i gospodarenja ekosustavima, kao i pri smanjivanju nepovoljnih ljudskih utjecaja na ekosustave i njihove usluge o kojima ovisi blagostanje sadašnjih i budućih generacija.

KLJUČNE RIJEČI: usluge šumskih ekosustava, općekorisne funkcije šuma, Park šuma Marjan, procjene usluga ekosustava

\section{UVOD}

\section{INTRODUCTION}

Čovjek je nakon dugog iskustva primanja koristi od različitih ekosustava i u vrijeme kada je biološka raznolikost na Zemlji sve više ugrožena, došao do spoznaja o značaju i vrijednostima svih ekosustava na Zemlji te potrebi njihovog pravilnog tretiranja, očuvanja i unaprjeđenja (Millennium Ecosystem Assessment, 2003). Vrijednosti ekosustava u novije vrijeme se nastoje utvrditi na temelju usluga koje oni pružaju čovjeku i drugim organizmima (Costanza et al. 1997). Čine se veliki napori kako bi se novčano vrednovale netržišne vrijednosti prirode i koristi od ekosustava (Boyd i Banzhaf, 2007; Brouwer et al., 2013). Tako je procijenjena usluga oprašivanja biljaka pomoću kukaca u EU na oko 15 milijardi EUR-a godišnje, jer oko 80\% usjeva u EU ovisi o oprašivanju i nestankom kukaca koji vrše oprašivanje izostao bi urod usjeva u tom iznosu (European Commission, 2011).

Čovjek procjenjuje vrijednosti ekosustava na temelju svog subjektivnog znanja i iskustva, iako je to znanje i iskustvo često skromno, pa čak i iracionalno (Dwyer et al., 1992). Općenito vrijednost je izraz ljudske želje i potrebe za jednom stvari u odnosu na drugu. Prema Spinosi „želimo ništa jer je to dobro, a to je dobro samo zato jer mi to želimo" (Jellesmark Thorsen et al., 2014). Vrijednost je subjektivno ljudsko iskustvo. Vrijednost prirode odnosno svega na Zemlji što nastaje samo po sebi treba promatrati u kontekstu života na Zemlji. Prema ljudskom iskustvu život je najveća vrijednost u Kozmosu. Bez života čovjek ne bi mogao spoznati sebe i prirodu koja ga okružuje.

Funkcije nekog sustava odnose se na njegovu namjenu i svrhu, a usluge na točno određenu korist. Funkcije sustava predstavljaju cilj funkcioniranja nekog sustava (npr. pružanje rekreacije u rekreacijskom centru), dok se usluge sustava odnose na ono što je napravljeno funkcioniranjem sustava, odnosno kvantitativni iskaz određene funkcije (npr. određeni broj sati različitih oblika rekreacije u rekreacijskom centru). Usluge ekosustava su vrijednosti prirode koje or- ganizmima omogućavaju život. Usluge šumskih ekosustava i funkcije šuma često se koriste u istom značenju, iako se djelomično razlikuju. Funkcija ili namjena šume može biti proizvodnja drvne tvari ili za odmor i rekreaciju, dok je usluga šumskog ekosustava količina proizvedene drvne tvari ili prostor u šumi gdje se odvija rekreacija. Funkcije šuma se odnose na namjenu i svrhu šuma, a usluge šumskih ekosustava su posljedice i rezultati funkcija šuma, odnosno koristi od ekosustava i svih njegovih komponenti za čovjeka i okoliš. Ljudi su oduvijek prepoznavali značaj funkcija šuma i usluga šumskih ekosustava. Stari Grci su znali o značaju očuvanja tla, odnosno o nepovoljnom utjecaju uništavanja šuma na tlo (Fisher et al., 2009). Alpsko stnovništvo je još prije nekoliko stoljeća spoznalo značenje šuma u zaštiti od erozije, bujica i lavina. Općenito šume imaju tri glavne funkcije: stvaranje drvne tvari, stvaranje drugih šumskih dobara (nedrvni proizvodi) i netržišne funkcije ili općekorisne funkcije šuma. Tako su npr. funkcije šuma na području Splita proizvodnja drvne tvari, proizvodnja drugih šumskih dobara i pružanje drugih koristi za čovjeka, dok su usluge šumskih ekosustava na području Splita godišnja količina proizvedene drvne tvari, godišnja količina proizvedenih drugih šumskih dobara te druge koristi od šuma za čovjeka. Koncept funkcija šuma i njihovog vrednovanja potječe od sredine 60 -ih godina 20 . stoljeća, dok se pojam usluge ekosustava pojavljuje početkom 80 -ih godina 20. stoljeća. Pojam usluga dolazi od riječi sluga, a označava skup radnji nekoga ili nečega koje su usmjerene na zadovoljenje potreba drugoga u ekosustavu. Usluge su skup određenih procesa za postizanje određenih koristi. U svakodnevnom životu koristimo brojne usluge: prijevozne, obrazovne, rekreacijske, trgovačke i dr. Kod tih usluga je jasno, tko daje uslugu, što ona predstavljaja, čemu ona koristi i zašto se plaća naknada za tu uslugu. Međutim, kod usluga ekosustava nije sve tako jasno. U novije vrijeme broj znanstvenih radova o uslugama ekosustava raste eksponencijalno (The Economics of Ecosystems and Biodiversity, 2010, Forest Europe Ministerial Conference on the Protection of Forests in Europe, 2014). Usluge ekosustava su koristi koje ljudi dobivaju od ekosustava, kao što su hrana, voda, drvo, odmor, duhovne koristi i dr. Usluge ekosustava su procesi i stanja pomoću kojih ekosustavi i organizmi u njima svojim funkcioniranjem omogućavaju određene izravne i neizravne koristi za život na Zemlji.

Postoje različite definicije usluga ekosustava. Prema Constanza et al. (1997) usluge ekosustava su koristi za ljudske populacije koje proizlaze izravno ili neizravno iz funkcija ekosustava. Daily et al. (1997) definiraju usluge ekosustava kao stanja i procese pomoću kojih prirodni ekosustavi i vrste koje ih čine, podržavaju i omogućavaju ljudski život. Prema Mileniskoj procjeni ekosustava (Millennium Ecosystem Assessment, 2003) usluge ekosustava su koristi koje ljudi dobivaju od ekosustava. 
Postoje i različite podjele usluga ekosustava (Daily et al., 1997; Millenium Ecosystem Assessment, 2003; Boyd and Banzhaf, 2007; Wallace, 2007; Fisher et al., 2009; UK NEA, 2011. i dr).

Općekorisne funcije šuma predstavljaju pružanje koristi za sve ljude i cijelu prirodu. To su najčešće netržišne koristi od šuma (engl. non-market forest functions). Šume pružaju mogućnosti za rekreaciju i razonodu, stanište za različite vrste organizama i atraktivne krajobraze. Šume imaju zaštitnu vrijednost (zaštita staništa, vrsta, rijetkih starih šuma, biološke raznolikosti, vode, kulturnog nasljeđa), okolišnu vrijednost, krajobraznu vrijednost (dizajn krajobraza sa šumama) i druge vrijednosti.

Općekorisne funkcije šuma postoje od kada postoji ljudska civilizacija. Svaki čovjek stalno koristi šume i njihove funkcije, iako toga nije ni svjestan. Čovjek oduvijek udiše zrak i kisik koje šume stvaraju, koristi vodu iz potoka koji se slijevaju iz šuma i koju šume pročišćavaju, kao i druge usluge koje šume pružaju, zaštitu tla od erozije, pohranjivanje $\mathrm{CO}_{2}$ i dr. (Prpić et al., 2009). U šumarstvu se već više od 50 godina koristi pojam općekorisne funkcije šuma, koji se odnosi na funkcije šuma koje koriste svim ljudima. Pojam usluge šumskih ekosustava odnosi se na sve funkcije šuma, dok se pojam općekorisne funkcije šuma odnosi samo na tzv. netržišni dio funkcija šuma.

Usluge ekosustava nisu novčano vrednovane i ne iskazuju se u društvenim obračunima. Zbog toga su ekosustavi i biološka raznolikost u njima sve više ugroženi i nestaju kao posljedica prekomjernih zahtjeva za prirodom i njenom upotrebom. Takav je primjer i Park šuma Marjan. Cilj rada je bio procijeniti novčanu vrijednost usluga i funkcija šumskih ekosustava Park šume Marjan.

\section{PODRUČJE ISTRAŽIVANJA I METODE RADA RESEARCH AREA AND METHODS}

\section{Obilježja Park šume Marjan u Splitu - The \\ characteristics of park forest Marjan in Split}

Park šuma Marjan predstavlja javni prostor posebnih prirodnih, kulturnih, povijesnih, socijalnih, obrazovnih, rekreativnih, duhovnih i drugih vrijednosti (slika 1). S njom upravlja Javna ustanova za upravljanje park šumom „Marjan“ $\mathrm{i}$ ostalim zaštićenim prirodnim vrijednostima na području Grada Splita. Površina park šume je oko 300 ha, od čega je oko 200 ha šuma, a ostalo su drugi ekosustavi.

\section{Šumski ekosustavi u Park šumi Marjan - Forest ecosystems in park forest Marjan}

Od 17. do 19. stoljeća šume na području današnje Park šume Marjan bile su potpuno uništene, zbog nepravilnog korištenja. Posljedica toga je bila erozija i pojava golog krša. Pri kraju 19. stoljeća započinje sustavno umjetno pošumljavanje na području Marjana. Predvodnik tih zahvata bio je splitski profesor Juraj Kolombatović, a najvažniju ulogu u pošumljavanju i uređenju puteva, staza i vidikovaca na Marjanu imalo je Društvo Marjan, koje je osnovano 1903. godine i koje se i danas brine o zaštiti Park šume Marjan.

U šumskim ekosustavima park šume Marjan glavna vrsta drveća je alepski bor (Pinus halepensis Mill.) s oko 94\% udjela u drvnoj masi, a druga najzastupljenija vrsta drveća je obični čempres (Cupressus sempervirens L.) s udjelom od oko 5\%. Ostale vrste drveća (brucijski bor, cedar, pinija, hrast medunac, hrast crnika i dr.) zastupljene su s oko $1 \%$ u ukupnoj drvnoj masi. Prosječna starost stabala alepskog

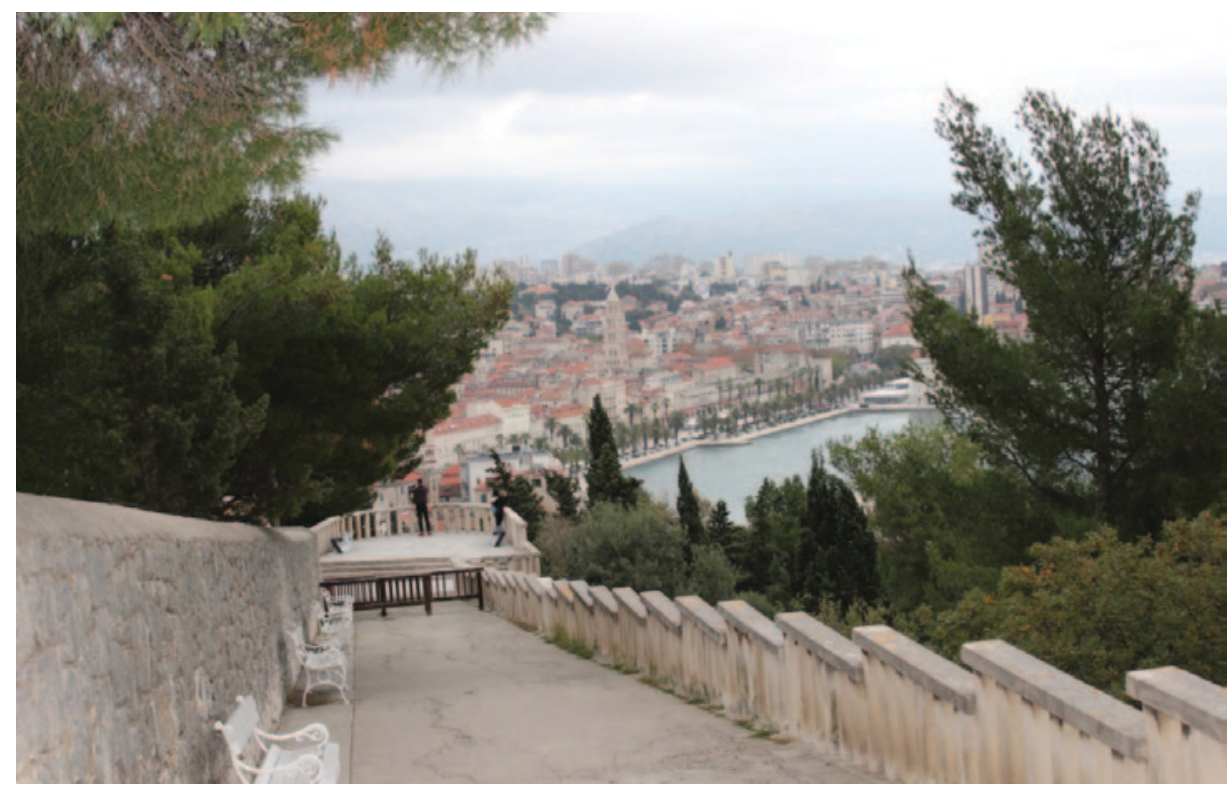

Slika 1 Grad Split i njegovi građani su povezani s park šumom Marjan mnogobrojnim vezama

Figure 1 Split and its inhabitans are linked with park forest Marjan by numerous ecosystem services 
bora je oko 90 godina. Šumski ekosustavi park šume Marjan za koje postoji program gospodarenja imaju površinu od 200 ha, dok postoji i dio šumskih ekosustava u park šumi Marjan koji nisu obuhvaćeni programom gospodarenja i za koje ne postoje točni podaci o površinama.

\section{Ostali ekosustavi u park šumi Marjan - Other ecosystems in park forest Marjan}

Na području park šume Marjan postoje i drugi ekosustavi kao što su vodeni i agroekosustavi, krške i izgrađene površine i dr. U radu su procijenjene vrijednosti usluga 200 ha šumskih ekosustava park šume Marjan za koje postoji program gospodarenja sa šumama.

\section{Obilježja grada Splita - The characteristics of Split}

Split je prema broju stanovnika drugi po veličini grad u Hrvatskoj. U njemu živi oko 178000 stanovnika. U urbanoj aglomeraciji Splita koja obuhvaća grad Split i 13 jedinica lokalne samouprave (područje od Trogira, Kaštela, Prgometa, Muća, Sinja, Dugopolja, Podstrane i Omiša do Šestanovca) živi oko 325000 stanovnika (Strategija razvoja urbane aglomeracije Split, 2016). Park šuma Marjan je najveća prirodna „zelena“ površina na području grada Splita i ima posebno značenje za stanovnike Splita i prepoznatljivost grada. S površinom od oko 300 hektara park šuma Marjan čini $12,5 \%$ površine grada Splita.

\section{Popis usluga šumskih ekosustava - List of forest ecosystem services}

U radu je napravljen originalan popis usluga šumskih ekosustava park šume Marjan prema međunarodnoj klasifikaciji usluga ekosustava (CICES od engl. The Common Inter- national Classification of Ecosystem Services; Haines-Young i Potschin, 2013; Kartiranje i procjena ekosustava i njihovih usluga u Hrvatskoj, 2015) i prema različitim podjelama OKFŠ (Prpić, 1992). Prema toj klasifikaciji postoje tri vrste usluga ekosustava koje se dalje dijele na sektore, skupine i klase. To su usluge opskrbe, usluge regulacije i podržavanja i kulturološke usluge. Ukupno se razlikuje 48 usluga ekosustava. Budući da ne postoji jedinstvena podjela funkcija i usluga šumskih ekosustava, napravljen je originalan popis usluga šumskih ekosustava koje se uočavaju u park šumi Marjan i koji je korišten za rangiranje i procjenu vrijednosti.

\section{Rangiranje usluga šumskih ekosustava - Ranking of forest ecosystem services}

Rangiranje usluga šumskih ekosustava park šume Marjan napravljeno je pomoću anketnih upitnika koje je popunilo 10 stručnjaka iz različitih institucija koji su sudjelovali na radionicama o procjeni usluga ekosustava park šume Marjan. Na prvoj razini rangiranja slovima A, B i C rangirane su usluge šumskih ekosustava s obzirom na njihovu važnost (A - najvažnije usluge, $B$ - srednje važne usluge i C - najmanje važne usluge šumskih ekosustava PŠM). U svakoj kategoriji bilo je potrebno izdvojiti podjednak broj usluga (9 do 10). Na drugoj razini rangiranja brojevima od 1 do 10 rangirane su samo najvažnije usluge šumskih ekosustava (oznaka A) ponovno prema važnosti (A1 - najvažnija, A2 -vrlo važna, A3 -važna, A4 do A6 - srednje važne i A7 do A10 - najmanje važne usluge šumskih ekosustava).

\section{Procjena vrijednosti usluga šumskih ekosustava - Value assessment of forest ecosystem services}

Vrijednosti usluga šumskih ekosustava se procjenjuju na temelju koristi koje čovjek ima od tih usluga. Te koristi

Tablica 1. Popis usluga šumskih ekosustava park šume Marjan u Splitu Table 1. List of forest ecosystem services of park forest Marjan in Split

\begin{tabular}{|lllll} 
& & $\begin{array}{c}\text { Usluge šumskih ekosustava park šume Marjan u Splitu } \\
\text { Forest ecosystem services of }\end{array}$ & park forest Marjan in Split \\
\hline 1 & Pružanje prirodnog prostora za odmor & 15 & Stvaranje povoljne mikroklime \\
2 & Prirodan prostor za druženje & 16 & Stvaranje kisika \\
3 & Prirodan prostor za zabavu & 17 & Stvaranje čistog i svježeg zraka \\
4 & Prirodan prostor za rekraciju & 18 & Primanje onečišćenja iz zraka \\
5 & Prirodan prostor za sportske aktivnosti & 19 & Razgradnja onečišćenja iz zraka \\
6 & Prirodan prostor za edukativne aktivnosti & 20 & Zaštita od štetnog UV zračenja \\
7 & Prirodan prostor za oporavak ljudi & 21 & Vezanje ugljičnog dioksida \\
8 & Prirodan i kulturni prostor za turističko posjećivanje & 22 & Reguliranje slijevanja i površinskog otjecanja vode \\
9 & Estetska funkcija u krajobrazu i okolišu & 23 & Pročišćavanje oborinske vode \\
10 & Povećanje kvalitete života građana koji žive u blizini park šume & 24 & Stvaranje plodnog šumskog tla \\
11 & Povećanje vrijednosti zemljišta i nekretnina u park šumi i njezinoj blizini & 25 & Zaštita prirodnih dobara u šumama \\
12 & Zaštita od vjetra & 26 & Pružanje životnih uvjeta za različite prirodne vrste biljaka \\
13 & Zaštita od erozije tla & 27 & Pružanje životnih uvjeta za različite prirodne vrste životinja \\
14 & Zaštita od bujica & 28 & Pružanje životnih uvjeta za različite prirodne vrste mikroorganizama
\end{tabular}


Tablica 2. Kriteriji i indikatori te novčana procjena izravnih koristi usluge pročišćavanja zraka u šumskim ekosustavima Park šume Marjan u Splitu

Table 2. Criteria and indicators and monetary assessment of direct benefits of air purification service in forest ecosystems of Park forest Marjan in Split

$\begin{array}{lll}\text { Kriteriji procjene } & \text { Indikatori procjene } \\ \text { Assessment criteria } & \text { Assessment indicators } \\ \begin{array}{ll}\text { Na temelju procjene godišnje količine } \\ \text { stvorenog zraka u PŠM }\end{array} & \begin{array}{l}\text { Godišnja količina biomase, odnos biomase i kisika, odnos volumena i težine tehničkih plinova, } \\ \text { cijena proizvodnje tehničkih plinova }\end{array} \\ \begin{array}{ll}\text { Na temelju ukupne cijene upravljanja i } \\ \text { održavanja Park šumom Marjan }\end{array} & \begin{array}{l}\text { Godišnja cijena upravljanja PŠM, ukupan broj usluga, postotak troška upravljanja za jednu } \\ \text { uslugu. }\end{array} \\ \begin{array}{ll}\text { Na temelju usporedne cijene pročišćavanja } \\ \text { zraka po volumenu prostora }\end{array} & \begin{array}{l}\text { Klimatizirani prostor u trgovačkim centrima, godišnja potrošnja energije sustava klimatizacije po } \\ \text { jedinci površine, cijena energije po kWh, odnos površine PŠM i potrebnog broja klima uređaja. }\end{array} \\ \begin{array}{ll}\text { Na temelju usporedne cijene pročišćavanja } \\ \text { zraka u malim prostorima }\end{array} & \begin{array}{l}\text { Potrošnja energije u klima uređajima u kućama, broj sati rada klima uređaja godišnje i danju, } \\ \text { cijena energije, odnos površine PŠM i potrebnog broja klima uređaja. }\end{array}\end{array}$

Tablica 3. Kriteriji i indikatori te novčane vrijednosti izravnih koristi rekreacijske usluge u šumskim ekosustavima Park šume Marjan u Splitu Table 3. Criteria and indicators and monetary assessment of direct benefits of recreation service in forest ecosystems of Park forest Marjan in Split

\begin{tabular}{|c|c|c|}
\hline $\begin{array}{l}\text { Kriteriji procjene } \\
\text { Assessment criteria }\end{array}$ & $\begin{array}{l}\text { Indikatori procjene } \\
\text { Assessment indicators }\end{array}$ & $\mathrm{kn} / \mathrm{ha}$ \\
\hline $\begin{array}{l}\text { Na temelju ukupne cijene upravljanja i } \\
\text { održavanja prirodnog prostora za } \\
\text { rekreaciju u Park šumi Marjan }\end{array}$ & Godišnja cijena upravljanja PŠM, ukupan broj usluga, postotak troška upravljanja za jednu uslugu. & 1.250 \\
\hline Na temelju troškova održavanja PŠM & $\begin{array}{l}\text { Površina održavanja prostora PŠM za rekreaciju (površinu asfaltnih cesta, kamenih staza, makadama i } \\
\text { staza po šumskim putevima), površina šuma u zonama rekreacije (dvije visine stabala x dužina cesta i } \\
\text { staza), postotak održavane površine PŠM za rekreaciju, trošak upravljanja za rekreaciju. }\end{array}$ & 2.262 \\
\hline $\begin{array}{l}\text { Na temelju usporedne cijene korištenja } \\
\text { prostora za rekreaciju u fitnes centru }\end{array}$ & Cijena rekreacije po satu u fitnes centru umanjena za opće troškove, ukupan broj sati rekreacije u PŠM. & 54.750 \\
\hline $\begin{array}{l}\text { Na temelju usporedne cijene korištenja } \\
\text { prostora za rekreaciju u gradu }\end{array}$ & $\begin{array}{l}\text { Cijena najma prostora za rekreaciju po satu, umanjena za osnovne troškove i porez, odnos površine } \\
\text { PŠM za rekreaciju i površine prostora za rekreaciju u gradu. }\end{array}$ & 58.000 \\
\hline Na temelju troškova prijevoza & Broj osoba koji se rekreira u PŠM, broj osoba koji plaća prijevoz do PŠM, cijena javnog prijevoza do PŠM. & 45.625 \\
\hline
\end{tabular}

mogu biti izravne i neizravne. Budući da se sve koristi usluga šumskih ekosustava ne mogu izmjeriti, vršimo različite procjene tih koristi kako bi smo dobili što bolje pokazatelje tih vrijednosti. Zbog toga se definiraju kriteriji i indikatori procjene usluga šumskih ekosustava. Kriteriji se odnose na definiranje određenih koristi, a indikatori na njihovu kvantitativnu vrijednost. Da bi se usluge mogle kvantificirati, moraju se jasno definirati. Definiranje i kvantificiranje usluga šumskih ekosustava obuhvaća utvrđivanje jednoznačnog naziva usluge, definiciju usluge, obrazloženje usluge, utvrđivanje korisnika usluge, izravnih koristi od usluge, neizravnih koristi od usluge, mjernih vrijednosti usluge, procjenu mjernih vrijednosti usluge i utvrđivanje vrijedsnoti usluge. U radu je napravljena procjena novčanih vrijednosti 5 najvažnijih usluga šumskih ekosustava PŠM pomoću različitih kriterija i dostupnih indikatora (tablice 2 i 3$)$.

\section{Metode vrednovanja usluga šumskih ekosustava - Value assesment methods of forest ecosystem services}

Ekonomska vrijednost nekog proizvoda i usluge je mjera njegovog doprinosa ljudskom blagostanju. Za utvrđivanje novčane vrijednosti usluga ekosustava koriste se različite metode (Brouwer et al., 2013). Prva skupina metoda su metode tržišnog vrednovanja (npr. na temelju vrijednosti drvne mase, vrijednosti plodova šumskog drveća i dr.). Međutim, mnoge usluge ekosustava nisu tržišno vrednovane, pa se za njihovo vrednovanje upotrebljavaju metode netržišnog vrednovanja kao što su metode otkivenih sklonosti, metode iskazanih sklonosti, metode troškova i prihoda i dr. Metoda plaćanja troškova temelji se na cijeni alternativnog osiguranja dobra ili usluge (npr. usluga pročišćavanja oborinske vode u šumama procjenjuje se na temelju alternativne mogućnosti plaćanja za tu uslugu u gradskom pročǐsćivaču voda, ili usluga oprašivanja biljaka se procjenjuje na temelju vrijednosti smanjenja prinosa kada ne bi bilo oprašivanja). Kod metode otkrivenih sklonosti vrijednost određene usluge se utvrđuje na temelju iznosa koji je netko spreman platiti za određenu uslugu. Metoda troškova putovanja omogućava utvrđivanje npr. rekreacijske vrijednosti nekog područja na temelju troškova putovanja koji nastaju pri posjeti određenom području. Metoda hedonističkog vrednovanja odnosi se npr. na to koliko kuća u blizini šume nekome više vrijedi, pruža veće zadovoljstvo i veće uživanje od kuća koje su dalje od šume (Anderson i Cordell, 1988). Metoda izbjegavanja troškova šteta temelji se na troškovima do kojih neće doći zbog usluga ekosustava. Npr. ako poplavna staništa štite od poplava, vrijednost zaštite od poplava može se utvrditi na temelju šteta koje se neće pojaviti ili na temelju izdataka vlasnika imovine za zaštitu imovine od poplave (Brauman i sur., 2007). Metoda zamjenskih troškova temelji se na troškovima osiguranja za- 
Tablica 4. Procjena novčane vrijednosti izravnih koristi 5 najvažnijih usluga šumskih ekosustava park šume Marjan u Splitu na temelju kriterija i indikatora pomoću različitih metoda

Table 4. Monetary value of direct benefits the five most important forest ecosystem services of park forest Marjan in Split assessed by criteria and indicators and different methods.

\begin{tabular}{|c|c|c|c|c|c|}
\hline \multicolumn{6}{|c|}{$\begin{array}{l}\text { Usluge šumskih ekosustava } \\
\text { Forest ecosystem services }\end{array}$} \\
\hline $\begin{array}{l}1 \text { Stvaranje čistog i } \\
\text { svježeg zraka }\end{array}$ & $\begin{array}{l}2 \text { Prirodan prostor za } \\
\text { rekraciju }\end{array}$ & $\begin{array}{l}3 \text { Pružanje prirodnog } \\
\text { prostora za odmor }\end{array}$ & $\begin{array}{l}4 \text { Stvaranje } \\
\text { kisika }\end{array}$ & $\begin{array}{l}5 \text { Prirodan prostor za } \\
\text { edukativne aktivnosti }\end{array}$ & Ukupno \\
\hline \multicolumn{6}{|c|}{$\begin{array}{l}\text { Procijenjena novčana vrijednost usluga prema različitim metodama (kn) } \\
\text { Monetary value of services assessed by different methods }(\mathrm{kn})\end{array}$} \\
\hline 249.970 & 249.970 & 249.970 & 249.970 & 249.970 & \\
\hline 100.000 & 452.317 & 452.317 & 16.260 & 262.500 & \\
\hline 31.285 .714 & 10.950 .000 & 5.770 .000 & & 30.000 & \\
\hline 30.000 .000 & $\begin{array}{r}11.400 .000 \\
9.125000\end{array}$ & 2.500 .000 & & & \\
\hline \multicolumn{6}{|c|}{$\begin{array}{l}\text { Prosjek procjena novčanih vrijednosti usluga (kn) } \\
\text { Average monetary value assessment of services (kn) }\end{array}$} \\
\hline 15.408 .921 & 6.435 .457 & 2.243 .072 & 133.115 & 180.823 & 24.401 .388 \\
\hline \multicolumn{6}{|c|}{$\begin{array}{l}\text { Prosjek procjena novčane vrijednosti usluga (kn/ha) } \\
\text { Average monetary value assessment of services (kn/ha) }\end{array}$} \\
\hline 77.045 & 32.177 & 11.216 & 666 & 904 & 122.008 \\
\hline
\end{tabular}

mjene za ekosustav ili uslugu. Metoda nadoknade troškova se temelji na troškovima povratka ekosustava ili njegove usluge na temelju procjene njihove vrijednosti. $\mathrm{U}$ ovom su radu napravljene procjene vrijednosti usluga šumskih ekosustava PŠM, ovisno o podacima koji su bili na raspolaganju. Aproksimativna procjena novčane vrijednosti svih usluga šumskih ekosustava PŠM napravljena je pomoću vrijednosti pet najvažnijih usluga. Svakoj od preostalih 23 usluge dodijeljen rang od 1 do $5 \mathrm{~s}$ obzirom na važnost usluge, koja je utvrđena anketom o rangiranju usluga. Zatim je svakom rangu pridružena prosječna procijenjena novčana vrijednost dobivena za 5 najvažnijih usluga šumskih ekosustava (rangu 1 najveća vrijednost, a rangu 5 najmanja vrijednost). Na temelju tih vrijednosti pojedinih usluga šumskih ekosustava park šume Marjan dobivena je ukupna vrijednost svih usluga šumskih ekosustava za 200 ha šuma park šume Marjan. Procjena vrijednosti OKFŠ park šume Marjan napravljena je na temelju ocjene OKFŠ u programu gospodarenja za PŠM (Program gospodarenja za PŠM, 2008), zatim na temelju procjene vrijednosti OKFŠ mediteranskih šuma (Prpić et al., 2011) i na temelju naknade za OKFŠ.

\section{REZULTATI}

\section{RESULTS}

\section{Usluge ekosustava Park šume Marjan - Ecosystem services of Park forest Marjan}

Usluge ekosustava nisu jasno definirane i postoje brojne podjele usluga ekosustava. Što se tiče šumskih ekosustava postoje i podjele funkcija šuma koje se razlikuju od podjela usluga ekosustava, pa je pitanje definiranja usluga šumskih ekosustava još kompliciranije. U tablici 1 naveden je popis
28 usluga ekosustava koje se pojavljuju u šumskim ekosustavima Park šume Marjan i koje su prepoznatljive za dionike i korisnike park šume. Taj popis ne obuhvaća sve usluge ekosustava, kao npr. uslugu proizvodnje drvne biomase, duhovnu uslugu i dr.

\section{Rangiranje usluga šumskih ekosustava Park šume Marjan - Ranking of forest ecosystem services of Park forest Marjan}

Na temelju obrade rezultata 10 anketa o rangiranju usluga šumskih ekosustava PŠM najvažnije usluge bile su stvaranje čistog i svježeg zraka, prirodan prostor za rekraciju i pružanje prirodnog prostora za odmor. Vrlo važne usluge bile su stvaranje kisika, prirodan prostor za edukativne aktivnosti i zaštita od erozije tla. Važne usluge bile su estetska funkcija u krajobrazu i okolišu, reguliranje slijevanja i površinskog otjecanja vode, prirodan i kulturni prostor za turističko posjećivanje i povećanje kvalitete života građana koji žive u blizini park šume. Slični rezultati su dobiveni i u anketi koju je provela agencija Hendal za udrugu Sunce iz Splita, a koja se odnosila na stavove građana Splita o park šumi Marjan i njenoj vrijednosti, (izvor udruga Sunce Split, 2016). Agencija Hendal je provela anketiranje metodom telefonskih intervjua, na uzorku od 700 građana Splita, starijih od 15 godina, reprezentativno zastupljenih prema spolu, dobi i gradskim četvrtima.

\section{Novčano vrednovanje usluga šumskih ekosustava Park šume Marjan - Monetary valuation of forest ecosystem services of Park forest Marjan}

Novčano vrednovanje usluga šumskih ekosustava park šume Marjan u Splitu napravljeno je za pet najvažnijih 
Tablica 5. Procijenjena novčana vrijednosti usluga šumskih ekosustava park šume Marjan u Splitu na temelju različitih kriterija procjene OKFŠ Table 5. Monetary value assessed of forest ecosystem services of park forest Marjan in Split based on different assessment methods of non-market forest functions

\begin{tabular}{|c|c|c|}
\hline \multicolumn{3}{|c|}{$\begin{array}{l}\text { Kriteriii procjene } \\
\text { Assessment criteria }\end{array}$} \\
\hline $\begin{array}{l}\text { Površina mediteranskih šuma Hrvatske i } \\
\text { ukupna vrijednost OKFŠ }\end{array}$ & $\begin{array}{l}\text { Ocjene OKFŠ PŠM, površine šuma u PŠM i } \\
\text { bodovne vrijednosti za ukupnu ocjenu }\end{array}$ & $\begin{array}{l}\text { Iznos naknade za OKFŠ u Hrvatskoj, odnos površine } \\
\text { šuma u Hrvatskoj i u PŠM }\end{array}$ \\
\hline \multicolumn{3}{|c|}{$\begin{array}{c}\text { Indikatori procjene } \\
\text { Assessment indicators }\end{array}$} \\
\hline $\begin{array}{l}\text { Odnos površine mediteranskih šuma ( } 776.304 \\
\text { ha) i procijenjene vrijednsoti OKFŠ mediteranskih } \\
\text { šuma Hrvatske ( } 239.563 .395 .000 \text { kn) i } \\
\text { površine šuma u park šumi Marjan ( } 200 \text { ha). }\end{array}$ & $\begin{array}{l}\text { Ocjena OKFŠ PŠM prema Pravilniku o uređivanju } \\
\text { šuma ( } 29.9) \text {, bodovna vrijednost za navedenu } \\
\text { ocjenu (402.103 boda), odnos broja bodova i kuna } \\
\text { (1:1), površina šuma PŠM ( } 200 \text { ha). }\end{array}$ & $\begin{array}{l}\text { Ukupna naknada za OKFŠ u Hrvatskoj (oko } \\
400.000 .000 \text { kn), ukupna površina šuma u Hrvatskoj } \\
\text { (oko 2.000.000 ha), iznos naknade za OKFŠ po hektaru } \\
\text { godišnje ( } 200 \text { kn), površina šuma PŠM ( } 200 \text { ha). }\end{array}$ \\
\hline \multicolumn{3}{|c|}{$\begin{array}{l}\text { Procijenjena novčana vrijednost usluga šumskih ekosustava PŠM (kn/ha) } \\
\text { Monetary value assessed of forest ecosystem services of park forest Marjan (kn/ha) }\end{array}$} \\
\hline 308.595 & 402.103 & 200 \\
\hline
\end{tabular}

usluga na temelju različitih kriterija i indikatora. U tablicama 2 i 3 prikazani su neki od kriterija i indikatora koji su korišteni za procjene izravnih koristi usluge pročišćavanja zraka i rekreacijske usluge u šumskim ekosustavima park šume Marjan. Novčane vrijednosti usluga iskazane su u kunama po hektaru.

U tablici 4 prikazane su različite novčane vrijednosti pet najvažnijih usluga šumskih ekosustva PŠM. Za različite usluge napravljen je različit broj procjena novčanih vrijednosti, iz kojih su izračunate prosječne novčane vrijednosti pojedinih usluga za 200 ha šuma park šume Marjan i po hektaru.

Procjena vrijednosti ostalih usluga šumskih ekosustava Park šume Marijan napravljena je na temelju novčanih vrijednosti pet najvažnijih usluga. Svakoj od ostalih usluga pridružena je jedna od dobivenih vrijednosti najvažnijih usluga prema kriterijima opisanim u metodama rada. Ukupna novčana vrijednost svih 28 usluga šumskih ekosustava Park šume Marjan je iznosila $708.042 \mathrm{kn}$ po hektaru godišnje, odnosno za 200 ha šumskih ekosustava Park šume Marjan 141.608.400 kn godišnje. U tabici 5 prikazane su procjene novčanih vrijednosti usluga šumskih ekosustava park šume Marjan na temelju procjena OKFŠ. Korišteni su podaci o procjeni vrijednosti mediteranskih šuma u Hrvatskoj, podaci o procjeni OKFŠ za park šumu Marjan iz osnove gospodarenja i podaci o naknadi za OKFŠ na razini Hrvatske.

\section{RASPRAVA I ZAKLJUČCI DISCUSSION AND CONCLUSIONS}

Većina ljudi danas prihvaća činjenicu da ekosustavi pružaju brojne koristi čovjeku i okolišu. Te koristi je često teško novčano vrednovati, pa se zbog toga rade i određene procjene, čiji je cilj naglasiti raznolikost usluga i njihovih koristi, a ne precizno izračunati ili utvrditi njihovu nov- čanu vrijednost. Procjene vrijednosti usluga šumskih ekosustava PŠM značajno su se razlikovale, s obzirom na kriterije i indikatore procjene. Važnije usluge šumskih ekosustava PŠM su imale i veću vrijednost. Raspon vrijednosti pet najvažnijih usluga šumskih ekosustava park šume Marjan je bio od 133.000 do 15.408.921 kuna godišnje, ovisno kriterijima i indikatorima procjene. Procjena vrijednosti svih usluga šumskih ekosustava PŠM iznosila je $708.042 \mathrm{kn}$ po ha godišnje, dok su procjene vrijednosti OKFŠ prema programu gospodarenja bile oko $402.000 \mathrm{kn}$, a OKF mediteranskih šuma oko $308.000 \mathrm{kn}$ po ha godišnje. Dobivene veće vrijednosti usluga šumskih ekosustava PŠM po jedinici površine u odnosu na procjene OKFŠ po jedinici površine su logične, zbog većeg broja usluga šumskih ekosustava (28) u odnosu na broj općekorisnih funkcija šuma koje se procjenjuju (9). Međutim, taj odnos nije bio proporcionalan. Park šuma Marjan predstavlja najvrjedniji dio prirode u gradu Splitu i njezina površina se ne smije smanjivati zbog usluga koje ona pruža svim stanovnicima grada Splita i ostalim posjetiteljima. Zaštita i upravljanje park šumom Marjan treba se stalno unaprjeđivati, kako bi se očuvale i povećale usluge ekosustava koje park šuma pruža ljudima i cjelokupnoj prirodi. Ukupna novčana vrijednost usluga šumskih ekosustava park šume Marjan procijenjena na $141.608 .400 \mathrm{kn}$. Procijenjena vrijednost se odnosi samo na usluge šumskih ekosustava koji čine 2/3 park šume Marjan. Ukupna vrijednost usluga ekosustava park šume Marjan je veća od procijenjene, jer ona ne obuhvaća vrijednost drugih ekosustava u park šumi Marjan za koje nije napravljena procjena. Naknada za OKFŠ koju plaćaju sve pravne osobe u RH za 28 usluga šumskih ekosustava park šume Marjan procijenjena je na 40.000 kn godišnje, odnosno 200 kn po hektaru godišnje. To je oko $7 \mathrm{kn}$ po ha godišnje po jednoj usluzi, odnosno oko $0,6 \mathrm{kn}$ po ha mjesečno za jednu uslugu šumskog ekosustava park šume Marjan. 


\section{ZAHVALA}

\section{ACKNOWLEDGEMENT}

Rezultati ovoga rada dobiveni su zahvaljujući potpori Udruge za prirodu, okoliš i održivi razvoj Sunce iz Splita, te se autori zahvaljuju na potpori.

\section{LITERATURA}

\section{REFERENCES}

- Anderson, L.M. and Cordell, H.K., 1988. Influence of Trees on Residential Property Values in Athens, Georgia, (USA): A Survey of Actual Sales Prices. Landscape and Urban Planning, 15, pp. 153-164.

- Boyd, J., Banzhaf, S., 2007. What are ecosystem services? The need for standardized environmental accounting units. Ecological Economics 63 (2-3), 616-626.

- Brauman, K.A., Daily, G.C., Duarte, T.K. and Mooney, H.A., 2007. The Nature and Value of Ecosystem Services: Highlighting Hydrologic Service. Annual Review of Environment and Resources, 32, pp. 67-98.

- Brouwer, R., Brander, L., Kuik, O., Papyrakis, E. and Bateman, I., 2013. A Synthesis of Approaches to Assess and Value Ecosystem Services in the EU in the Context of TEEB. Final Report. TEEB Follow-up Study for Europe, University Amsterdam, Institute for Enviromental Studies, pp. 1-144.

- Costanza, R.R., d'Arge, R., de Groot, R., Farber, S., Grasso, M., Hannon, B., Limburg, K., Naeem, S., O’Neill, R.V., Paruelo, J., Raskin, G., Sutton, P. and Van den Belt, M., 1997. The Value of the World's Ecosystem Services and Natural Capital. Nature, 387, pp. 253-260.

- Daily, G.C., Alexandr, S., Ehrlich, P.R., Goulder, L., Lubchenco, J., Matson, P.A., Mooney, H.A., Postel, S., Schneider, S.H., Tilman, D. and Woodwell, G.M., 1997. Ecosystem Services: Benefits Supplied to Human Societies by Natural Ecosystems. Issues in Ecology, No. 2, Ecological Society of America, pp. 1-18.

- Dwyer, J.F., Mcpherson, E.G., Schroeder, H.W. and Rowntree, R.A., 1992. Assessing the Benefits and Costs of the Urban Forest. Journal of Abroriculture, (18)5, pp. 227-234.

- European Comminssion, 2011. Communication from the Commission to the European Parliament, the Council, the Economic and Social Committee and the Committee of the Regions. Our Life Insurance, Our Natural Capital: an EU Biodiversity Strategy to 2020. COM(2011)244 finals. Brussels.

- Fisher, B., Turenr, K.R., Morling, P., 2009. Defining and classifiyng ecosystem services for decision making. Ecological Economics 68 (3), 643-653.
- Forest Europe Ministerial Conference on the Protection of Forests in Europe, Liaison Unit Madrid. Expert Group and Workshop on a Pan-european Approach to Valuation of Forest Ecosystem Services, 2014. Belgrade Workshop, Final Report, pp. $1-98$.

- Haines-Young, R. and Potschin, M., 2013. Common International Classification of Ecosystem Services (CICES): Consulation on Version 4, August-December 2012. Report to the European Environment Agency. Centre for Environmental Management, University of Nottingham, UK.

- Jellesmark Thorsen, B., Mavsar, R., Tyrvalnen, L., Prokofieva, I. and Stenger, A., 2014. The Provision of Forest Ecosystem Services. Volume I: Quantifying and Valuing Non-marketed Ecosystem Services. European Forest Institute, pp. 1-76.

- Kartiranje i procjena ekosustava i njihovih usluga u Hrvatskoj, 2015. Agencija za zaštitu okoliša, str. 1-108.

- Millennium Ecosystem Assessment, 2003. Ecosystems and Human Well-being: A Framework for Assessment. Washington, DC: Island Press. (Online). Available at: http://www.unep.org/ maweb/documents/document.765.aspx.pdf. Accessed: 10/10/2011.

- Program gospodarenja za šume s posebnom namjenom g. j. Park šumu Marjan, 2008. Šumarski fakultet Sveučilište u Zagrebu.

- Prpić B., 1992. Ekološka i gospodarska vrijednost šuma u Hrvatskoj. Šume u Hrvatskoj, „Hrvatske šume“ p.o. Zagreb, str. 237-256, Zagreb.

- Prpić, B., Seletković, Z., Tikvić, I., 2009. Prašuma Čorkova uvala u svjetlu pružanja općekorisnih funkcija šuma. Zbornik radova znanstvenog skupa „Prašumski ekosustavi dinarskog krša i prirodno gospodarnje šumama u Hrvatskoj", HAZU, Znanstveno vijeće za poljoprivredu i šumarstvo, Sekcija za šumarstvo, str. 125-133.

- Prpić, B., Pernar, R., Jurjević, P., Milković, I., Vrebčević, M., Petreš, S., 2011. Kartiranje općekorisnih funkcija šuma u Sredozemlju, u: Šume hrvatskog Sredozemlja, Matić, Slavko (ur.), Akademija šumarskih znanosti, str. 288-294., Zagreb.

- Strategija razvoja urbane aglomeracije Split, 2016, str. 1-138.

- The Economics of Ecosystems and Biodiversity (TEEB): Mainstreaming the Economics of Nature: A Synthesis of the Approach, Conclusions and Recommendations of TEEB, 2010. pp. 1-39.

- UK National Ecosystem Assessment, 2011. The UK National Ecosystem Assessmen: Synthesis of the Key Findings, UNEPWCMC, Cambridge.

- Wallace, K.J., 2007. Clasification of ecosystem services: problems and solutions. Biological Consevation 139 (3-4), 235-246.

\section{Summary}

Forest ecosystem services and forest functions have similar meaning with partial differences. Forest functions refer to forests' purposes beneficial to people, while ecosystem services are results of forest functions and still present the benefits of ecosystems to people and environment. Ecosystem services cover all forest functions, whereas non-market forest functions are those which are used by all people. Park forest Marjan with its many ecosystems offers many services and benefits to the inhabitants of Split, park forest visitors and other organisms. Of the 300 ha area of park forest Marjan, forest ecosystems are most prevalent and account for $2 / 3$ of the park forest area. In this paper, 28 forest ecosystem services of park forest Marjan were defined for the first time based on the international ecosystem services classification and other non-market forest function clas- 
sifications. Services were ranked by means of a questionnaire of stakeholders. The five most important services were the production of clean and fresh air, natural space for recreational activities, natural space for leisure, oxygen production and natural space for educational activities. Monetary value of the five most important services was assessed using several different estimation methods based on certain criteria and indicators. Estimated values of individual most important services ranged from 700 kuna to 77.000 kuna per ha per year. Total estimated value of those services amounted to 122.000 kuna per ha per year, that is, 24,4 million kuna per year for the 200 ha of forests in park forest Marjan. Furthermore, approximative monetary value assessment was performed for other 23 forest ecosystem services. As a result, the total estimated value of all 28 services was 708.000 kuna per ha per year, that is, around 141,6 million kuna per year for the 200 ha of forests in park forest Marjan. Obtained results were validated using assessment of non-market forest functions according to the management plan of park forest Marjan, assessment of non-market forest functions of mediterranean forests and the annual amount of non-market forest function fees, with estimated values ranging from 200 kuna to 402.000 kuna per ha per year. Monetary assessment of forest ecosystem services is key in the management and protection of ecosystems, as well as in reducing of adverse human influences on ecosystems and their services, which serve to the welfare of current and future generations.

KEY WORDS: forest ecosystem services, non-market forest functions, park forest Marjan, assessment of ecosystem services 